\title{
CHAPTER 1 \\ IMPROVING THE SYSTEM OF INDICATORS \\ OF EFFECTIVE FINANCIAL SUPPORT \\ FOR SOCIAL PROTECTION
}

\section{Barannik L. B.}

\section{INTRODUCTION}

The result of any activity is linked to its purpose, which is interpreted as a planned result, an ideal, conceivable prediction of the end of the activity. The result of social protection of the population in the form of the beneficial effect of labor is to meet the social needs of vulnerable sections of the population, as well as to improve their social well-being, to solve the difficult life situation with the least cost (material, financial, labor, time). Any result should be evaluated in terms of achieving the goals. In economic science, the efficiency indicator is calculated as the ratio of achieved results to the resources used. How effective an activity has sometimes been can be judged by the results themselves, comparing them by year with similar indicators of other periods or other countries. The specificity of the assessment of financial support for social protection of the population is that, in addition to quantitative characteristics, the result should have a social effect, that is, a significant useful value for the individual and society. The result of financial support for social protection should be to raise the standard of living not only of those persons or social groups to whom social protection is provided, but of the whole population. The effectiveness of financial provision for social protection is ultimately manifested itself as a long-lasting positive trend in the well-being of the population. Therefore, this effectiveness should be assessed by determining its economic and social component. The latter is linked to the concept of externalities (external effects), which have no monetary dimension, are not taken into account by the market, but "cause deviations of private marginal products and costs from social marginal products and costs, breaking equilibrium". Arthur Pigou laid the basic understanding of the concept in 1920 in the book "The Economics of Welfare". The term "externalities" in

\footnotetext{
${ }^{1}$ Pigou A.C. (1920). The Economics of Welfare. London: Macmillan. 953 p. URL: http://pombo.free.fr/ pigou1920.pdf.; The Economics of Welfare. URL: https://www.britannica.com/ topic/The-Economics-ofWelfare
} 
the 50's of the twentieth century was introduced by Paul Samuelsson into scientific circulation, he replaced the term "external economies or loss" of Alfred Marshall ${ }^{2}$. There are positive (improvement of health, growth of educational level of the population, etc.), and negative (pollution of environment, reduction of life expectancy) of externalities. The destructive influence of the latter is called upon by the state. Therefore, the activity of a state or economic entity is considered socially effective, if it will help to eliminate or minimize the negative effects of external effects or stimulate the expansion of positive externalities.

\subsection{General information on social protection indicators}

Specific characteristics are to indicate the effectiveness of social protection: social indicators and effective indicators. For example, the increase in the well-being of the population is an important indicator of social progress, and the indicators that express well-being may be several (increase in real wages, decrease in the share of food costs in the family budget, etc.). Social indicators mainly reflect the increase / decrease in the material and cultural development of society at the level of the "average individual", they allow medium-term planning to be carried out only by simple extrapolation from what has been achieved and are not able to give a differentiated characteristic of all complex changes in social processes. "In this sense, the system of social indicators is a necessary complement to social indicators and allows us to speak with scientific certainty about the specific working conditions and life of a person and their impact on his behavior and activity, people's attitude to living conditions and the like. The system of social indicators is capable of providing direct information about the mechanisms of action and the form of manifestation of social patterns in people's activities"3.

It is necessary to distinguish between the indicators that characterize the work of the social protection system of the population and the indicators that indicate the effectiveness of the use of social protection funds. It is not the same thing. However, in fact, the success of social protection is a consequence of sufficient funding. We believe that social indicators, which symbolize the effectiveness of financial support for the social protection system of the population, can be grouped into these two groups and expressed by a number of indicators:

\footnotetext{
2 Samuelson P. (1955). Diagrammatic exposition of the theory of public expenditure. Review of Economics and Statistics, no. 37.

${ }^{3}$ Тропіна В.Б. Фіскальне регулювання соціального розвитку суспільства. Київ : НДФІ, 2008. 50 с.
} 
Group 1 - "social security of the country", its indicators:

- The growth of the Human Development Index;

- Positive dynamics of the share of government spending on social protection of the population in the GDP structure;

- Positive dynamics of national per capita income;

- Gini coefficient;

- Significant reduction of property stratification;

- The level of unemployment within the norm or its significant reduction;

- Reduction of absolute poverty by international and combined criteria;

- Gradual reduction of poverty by structural criteria and caloric intake;

- Stable or reduced poverty situation;

- International ratings;

Group II - "social protection of the population", its indicators:

- Increase in the share of social protection expenditures in GDP, Consolidated Budget, State and / or local budgets;

- Positive dynamics of social standards, norms and norms;

- Positive dynamics of real wages;

- Low inflation;

- Subjective determination of a person's degree of self-protection, etc.

Of course, this list is not exhaustive. The first group of indicators is mainly used in international comparative studies; they are of a general nature. The second is usually used to analyze trends in the country or region.

Efficiency is the value of a variable and the idea of efficiency is a variable. Often, what was considered effective $40-50$ years ago might not meet current criteria of efficiency and usefulness. For example, in world statistics, the increase in the share of government spending on social protection of the population in the gross domestic product is a major indicator. On the one hand, it is a fact of increasing state attention to the social protection of the population, and on the other - it can mean an increase in the number of those who need social support. Efficiency has different forms of manifestation and in each case, it is necessary to weigh carefully what was expected from an event and what was received.

Ukrainian statistics use a set of social indicators and social protection indicators. Therefore, the statistical collection "Social Protection of the Population of Ukraine" contains 114 indicators on general information at the macroeconomic level, information on the pension provision and on 
social protection of certain categories of the population ${ }^{4}$. It provide a certain idea of different aspects of social protection. In our opinion, this collection needs to be improved through a number of points. First, in the State budget the item of expenditures on social protection of the population is called "Social protection and social security", but it does not reflect the real costs of social protection.

Secondly, in section 3 "Social protection of the population", besides general information (such as the number of persons with disabilities, etc.), information on social assistance, state content of the disabled categories and provision of social services is concentrated. That is, it is about social security. It would be appropriate to supplement the information on a number of indicators showing the results of social security separately by population groups and categories of citizens.

Third, the information in this section is limited because there are no data on social norms and regulations, for example, the amount of funds for the maintenance of one child in an orphanage, the cost of treatment or education of one child in a specialized boarding school, and the like. Section 2 "Pension provision" lacks information on non-state pension provision.

Fourth, there is no information on wages (except item 1.4. "Ratio of the average amount of the appointed monthly pensions and the average monthly wage"), which is one of the main social indicators of the living standards of the working population.

Fifth, the current state of society development also requires the provision of information on household self-defense capabilities. It would be advisable in a separate section together with the quantitative characteristics of households (the number of households in urban and rural areas, the number of families with two, three or more children and income per family member in such families etc.) to indicate some financial characteristics (dynamics of savings, the average cost of food per family member or medical care etc.).

Sixthly, there is no information about social assistance to victims of catastrophes of a man - made disasters, natural or other emergency nature.

Seventhly, the collection devoted to social protection of the population should include information on social insurance (it is advisable in a separate section).

\footnotetext{
${ }^{4}$ Соціальний захист населення України. Статистичний збірник. Відп. за випуск І.В. Калачова. Київ : Державна служба статистики України, 2012. 119 с.
} 
A number of indicative indicators of the effectiveness of financial support for social protection should also be included in this collection. This is the proportion of citizens who have received a particular type of social assistance, the total number of those who need it or have applied to social protection bodies, as well as the proportion of those whose financial status has improved as a result of receiving one or another type of social assistance.

\subsection{Scientific approaches to the essence of efficiency}

There are several general criteria for determining effective spending: economically, without loss, within the specified amount with greater effect. In the first case, the result is achieved using the least money (the indicator is the amount of cost savings). In the second, there is a targeted use within the planned amount, so to speak, the utilization of the allocated amount (the indicator is the percentage of the plan implementation, the conformity of the expenses of the budget). In the third case, the best result is achieved by using the budgeted amount of funds (an indicator is the increase in the amount of expenses per one need while reducing those in need of protection, the amount from reducing unproductive costs, etc.). Sometimes the latter principle is implemented through a competition, where the evaluation of proposals is by different criteria and the purpose is to conclude a contract on the best terms.

According to Yu.D. Radionov, who notes that in economic science, efficiency is determined qualitatively and quantitatively by three principles: productivity, "resultivity" and economy ${ }^{5}$. The methods of evaluation are constructed on this basis. These are: 1) comparative analysis: the results achieved in the previous years are compared with the defined goals and alternative ways of solving certain problems are compared; 2) factor analysis: is a statistical approach, which is based on the impact of changing factors on the result; 3) data packet analysis: investigates the relationship between resources and results in terms of maximum performance achieved by the most progressive organizations.

In modern scientific studies, there is no single approach to defining the criteria and indicators of the effectiveness of the provision of social services, which in particular are the services of the social protection system. The recipient assesses the quality and accessibility of the services,

\footnotetext{
${ }_{5}^{5}$ Радіонов Ю. Проблема ефективності використання бюджетних коштів. Фінанси Украӥни. 2011. № 5. C. $47-55$.
} 
but the contractor assesses the adequacy of the funds and other protection parameters, and whether the process of providing social services to the end consumers is implemented as planned (comparing actual achievements with the planned ones). Therefore, for a qualitative assessment of the phenomenon of social protection, analytical, sociological, statistical, heuristic and other methods should be used.

The principle of cost savings does not always mean rational or optimal use. Thus, the optimization of the general educational schools in Ukraine during the entire of transformational period has led to some cost savings for these institutions. Since 1995, the number of schools in rural areas has decreased by more than two thousand. This was one of the reasons that many school-age children in rural areas lost the opportunity to attend comprehensive school. The damage to the socio-economic potential of this "economy" is difficult to determine. The emergence of such a number of people with low educational level in the labor market in the near future will significantly complicate their employment and require considerable funds for their "training", the value of which may exceed the costs saved from the enlargement of the network of comprehensive schools. In addition, this measure of "economy" entails the need to implement the social program "School Bus" and the problem of employment of released teachers.

The second example. The purchase of the well-known medical antiviral drug "Tamiflu" during the influenza epidemic in 2010 spent almost the annual budget of the Ministry of Health of Ukraine. However, the expected epidemic did not happen. The drug remained unclaimed. By the way, in Ukraine, about 20000 people die from seasonal flu annually, while over 400,000 die from cardiovascular disease (440.3 thousand in $2011,384.8$ thousand in 2017), from oncological diseases 80-90 thousand (89.0 thousand in 2011, 78.3 thousand in 2017) ${ }^{6}$. Consequently, such expenditure can unlikely be considered justified.

It can never say that maximum efficiency has been achieved and nothing else can be done. Circumstances change; requirements change, new opportunities, methods and technologies emerge. Performance evaluation should occur regularly through realistic evaluation cycles.

The effectiveness of financial provision for social protection needs can be determined by the factor of provision as a result of the ratio of allocated funds to the need. For example, a measure requires UAH 50 million,

\footnotetext{
${ }^{6}$ Статистичний щорічник України за 2011 рік. За ред. О.Г. Осауленка. Київ : ТОВ «Август Трейд», 2012. 556 с.; Населення Украйни за 2017 рік. Демографічний щорічник. Державна служба статистики Украӥни. С. 113.
} 
UAH 35 million is allocated. That is, the event is funded by $70 \%$. Coefficient of provision is 0.70 . Of course, the closer it is to 1 , the better the need is met. But, if the need is calculated according to outdated standards, even with its $100 \%$ funding, sufficiency will be pseudoeffective. Therefore, the problem must be solved comprehensively - using various indicators, or a set of indicators, or using different methods.

The common method of calculating the economic effect for the year by the formula:

$$
\mathrm{EE}_{\mathrm{y}}=\mathrm{E}_{\mathrm{y}}-\mathrm{E}_{\mathrm{nc}} * \mathrm{C}
$$

where $E_{\mathbf{y}}$ is the annual savings or results achieved through specific activities;

$E_{n c}$ - normative coefficient of efficiency; a constant value that depends on the specific area of activity;

$\mathrm{C}$ - the cost of the specific activity for which the economic impact is calculated.

Ukrainian scientist O. A. Lanovenko proposes a formula for evaluating the effectiveness of social services ${ }^{7}$.

$$
\mathrm{E}=(\mathrm{R} / \mathrm{PA}+\mathrm{C}+\mathrm{CA})+(\mathrm{QS}+\mathrm{AS}+\mathrm{AHF}), \text { where }
$$

$\mathrm{E}$ - efficiency; $\mathrm{R}$ - result, PA - the purpose of the activity, $\mathrm{C}$ - the cost, $\mathrm{CA}$ - the conditions of activity, QS - quality of service, AS - availability of service, $\mathrm{AHF}$ - focus of service on activation of the vital forces.

The effectiveness index is calculated on a scale of 1 to -1 . According to O. Lanovenko, the quality of service is a combination of characteristics that reflect the ability of the service provided to meet the needs and interests of its recipient. The accessibility of the service is characterized by the conditions of access to the territories, premises within which the services are provided; providing the population with information about the work of social institutions, types of services etc. Activation of the vital forces of the unprotected person in the process of providing social services should include an increase in the level of social activity of the client, the desire to seek a way out of a difficult situation themselves, etc.

In our opinion, the idea itself is interesting, but a number of components of this formula are difficult to quantify and therefore unsuitable for practical work.

\footnotetext{
7 Лановенко О.А. Социальная эффективность предоставления социальных услуг: критериальные показатели ее оценки. Вісник Харківського національного університету імені В.Н. Каразіна. 2010. № 889. C. $142-147$.
} 
Social effect is a kind of analogue of economic effect. It cannot be calculated on a cost-benefit principle. However, since the social effect is the result of transformations in the social sphere, its calculation must be aimed at a clear result. For this purpose, the effect indicators should be determined through the natural or value indicators of the investment activity, that is, in terms of investment.

The effectiveness of financial support for social protection depends primarily on the management of expenditures of a certain budget for social protection as a determining component of the process of using budget funds. The effectiveness of the use of budget funds should be understood as the achievement of goals and objectives in the framework of the implementation of state programs by correlating the result and costs (volume of expenses). The economic efficiency of social spending budget can be defined as the monetary value of the economic effect (increase in local budget revenues) in relation to the spent social expenditures, by the formula:

$$
\mathrm{EE}_{\mathrm{SE} L B}=\Delta \mathrm{BP}_{\mathrm{LBi}} / \Delta \mathrm{SE}_{\mathrm{LBi}-1} \text {, where: }
$$

$\mathrm{EE}_{\mathrm{SE} L B}$ - economic efficiency of expenditures of local budgets of social purpose;

$\triangle \mathrm{BP}_{\mathrm{LBi}}$ - increase in local budget revenues in the $i$-th period, caused by the effect of social expenditures in the previous period;

$\Delta \mathrm{SE}_{\mathrm{LBi}-1}-$ increase in expenditures of local social purpose budgets.

Let us illustrate with the example of the budget of one of the districts of the city of Dnipro, how the formula below can determine the economic effectiveness of spending on social protection and education (Table 1).

According to the results of the calculations, it can be concluded that the costs should be more cost-effective in the pre-crisis period, while in this area there is a tendency to reduce the efficiency of expenses in the most priority areas every year.

We propose a method of assessing the effectiveness of financial support for social protection of the population. It can be used to determine the effectiveness of the implementation of social programs or individual measures of social protection; it gives an opportunity to evaluate not only the nature of the use of funds for the event, but also the social effect of it. The method is to calculate the coefficient of efficiency of use of budgetary funds $\left(\mathrm{KE}_{\mathrm{i}}\right)$ and is carried out in three stages: 
Table 1

Calculation of economic efficiency of expenditures

\begin{tabular}{|c|c|c|c|c|c|}
\hline Year & $\begin{array}{c}\text { Expenditure } \\
\text { on the social } \\
\text { protection, } \\
\text { thousand } \\
\text { UAH } \\
\left(\mathrm{SE}_{\text {LB soc }}\right)\end{array}$ & $\begin{array}{c}\text { Expenditure } \\
\text { on } \\
\text { education, } \\
\text { thousand } \\
\text { UAH. } \\
\left(\mathrm{SE}_{\text {LBedu }}\right)\end{array}$ & $\begin{array}{c}\text { Revenues, } \\
\text { thousand } \\
\text { UAH. } \\
\left(\mathrm{BP}_{\text {LBi }}\right)\end{array}$ & $\begin{array}{c}\text { Economic } \\
\text { effectiveness } \\
\text { of social } \\
\text { protection } \\
\text { expenditures } \\
\left(\text { EE }_{\text {SEsoc }}\right)\end{array}$ & $\begin{array}{c}\text { Economic } \\
\text { effectiveness } \\
\text { of education } \\
\text { expenditures } \\
\left(\text { EE }_{\text {SEedu }}\right)\end{array}$ \\
\hline 2005 & 5673,20 & 16337,70 & 74327,56 & - & - \\
\hline 2006 & 6889,20 & 21560,50 & 76566,89 & 13,5 & 4,7 \\
\hline 2007 & 20774,88 & 26476,70 & 78237,20 & 11,4 & 3,7 \\
\hline 2008 & 27938,98 & 41226,83 & 79547,17 & 3,8 & 3,0 \\
\hline 2009 & 44251,50 & 47247,43 & 105479,91 & 3,8 & 2,6 \\
\hline 2010 & 57147,20 & 55573,65 & 127818,85 & 2,9 & 2,7 \\
\hline 2011 & 63502,10 & 55402,00 & 132931,20 & 2,3 & 2,4 \\
\hline 2012 & 70557,30 & 72059,30 & 159932,37 & 2,5 & 2,9 \\
\hline
\end{tabular}

Source: calculated by the author

1) assessing the achievement of the target indicators for each line of expenditure (i); the indicator can be represented as the coefficient of the degree of achievement of the planned indicative (recommendatory) indicators for each direction of spending of budgetary funds (CD and PI), it can also be considered as the coefficient of social effect, and calculated by the formula:

$$
\mathrm{K}_{\mathrm{PIi}}=\left(\begin{array}{c}
\mathrm{k} \\
\left.\mathrm{F}_{\mathrm{i}} / \mathrm{P}_{\mathrm{i}}\right) / \mathrm{k} \text {, where: }
\end{array}\right.
$$

$\mathrm{K}_{\mathrm{PI}}$ - the degree (coefficient) of achievement of the planned indicators;

$\mathrm{F}_{\mathrm{i}}$ - the actual value of the indicator for $\mathrm{N}$ year;

$\mathrm{P}_{\mathrm{i}}$ - the planned value of the indicator for $\mathrm{N}$ year;

$\mathrm{k}$ is the number of indicators for the direction of spending of budgetary funds;

2) assessing the completeness of the use of budgetary funds for each line of expenditure of budgetary funds (i); the estimated indicator can be represented as the coefficient of completeness of use of budgetary funds $\left(\mathrm{K}_{\mathrm{CBFi}}\right)$ for each direction of spending of budgetary funds, and calculated by the formula:

$$
\mathrm{K}_{\mathrm{CBFi}}=\mathrm{F}_{\mathrm{i}} / \mathrm{P}_{\mathrm{i}} \text {, where: }
$$


$\mathrm{K}_{\mathrm{CBFi}}$ - the coefficient of completeness of the use of budgetary funds for each direction of spending of budgetary funds;

$\mathrm{F}_{\mathrm{i}}$ - the actual expenditures of budgetary funds in the $i$-th direction of their spending in $\mathrm{N}$ year;

$\mathrm{P}_{\mathbf{i}}$ - the planned expenditures of budgetary funds in the $i$-th direction of their spending in $\mathrm{N}$ year;

3 ) assessing the effectiveness of financial support for social protection of the population in the $i$-th direction in $\mathrm{N}$ year, which comes down to calculating the efficiency ratio of budgetary funds $\left(\mathrm{K}_{\mathrm{Fi}}\right)$, and calculated by the formula:

$$
\mathrm{K}_{\mathrm{Ei}}=\mathrm{K}_{\mathrm{PI} \mathrm{i}} / \mathrm{K}_{\mathrm{CBFi}} \text {, where: }
$$

$\mathrm{K}_{\mathrm{Ei}}$ - the coefficient of the effectiveness of the use of budgetary funds in the $\mathrm{i}$-th direction in $\mathrm{N}$ year.

If $\mathrm{K}_{\mathrm{Ei}}=1$, this indicates high cost-effectiveness. A consolidated estimate of the planned budgetary efficiency can be found as the sum of the estimates for each area. In some cases (depending on the purpose of the task), the resulting performance indicator can be adjusted to an additional calculated factor of social effect. The latter takes various forms (security of the needy, coverage of persons in need of protection, etc.). This method is simple enough and can be applied in the practical work of social protection bodies and institutions of social services.

\subsection{Modeling of the integral indicator of social self-protection of households}

Efficiency is the result of a number of efforts to achieve these goals. Sometimes efficiency can be estimated by constructing an integral metric from several others. This is characteristic of assessing such an indicator of effectiveness as social protection; it focuses all efforts of the state (authorities) to improve the welfare of the population.

The use of different indicators to determine the level of socioeconomic security creates the problem of their measurement and combination, which can be solved based on the use of relative indicators, in particular, it can be a score in points. We will show this using our research as an example. We tried to assess the importance of the factor or group of factors affecting the level of self-protection of households (LPH) for different population groups by questioning and calculating the integral coefficient for each group of respondents. Pupils, students, workers and pensioners attended the survey. Table 2 shows the data characterizing the 
values of factors affecting the LPH, on a 100-point scale, residents of Dnipropetrovsk region. There are two groups of factors: "Material factors" $F_{1}(F 11-F 20)$ and "Intangible factors" $F_{2}(F 21-F 30)$.

Table 2

\section{Assessment of the factors affecting the level of self-protection of households on a 100-point scale}

\begin{tabular}{|c|c|c|c|c|c|}
\hline \multirow{2}{*}{$\begin{array}{l}\text { № } \\
\text { w/o }\end{array}$} & \multirow{2}{*}{ Factors } & \multicolumn{4}{|c|}{$\begin{array}{l}\text { The average value of the factor by groups } \\
\text { of respondents, points }\end{array}$} \\
\hline & & $\begin{array}{c}\text { Pupils } \\
\left(\mathrm{x}_{1}\right)\end{array}$ & $\begin{array}{c}\text { Students } \\
\left(\mathrm{x}_{2}\right)\end{array}$ & $\begin{array}{c}\text { Workers } \\
\left(\mathrm{x}_{3}\right)\end{array}$ & $\begin{array}{c}\text { Pensioners } \\
\left(\mathrm{x}_{4}\right)\end{array}$ \\
\hline \multicolumn{6}{|c|}{ Material factors $F_{1}$} \\
\hline 1 & $\begin{array}{l}\text { Income (salary, pensions, } \\
\text { scholarships) }\left(\mathrm{F}_{11}\right)\end{array}$ & 18,1 & 15,2 & 24,2 & 50,0 \\
\hline 2 & Taxes $\left(\mathrm{F}_{12}\right)$ & 12,3 & 10,8 & 10,8 & 7,8 \\
\hline 3 & Prices $\left(F_{13}\right)$ & 11,4 & 10,7 & 10,0 & 10,5 \\
\hline 4 & Interest on loans $\left(\mathrm{F}_{14}\right)$ & 10,3 & 9,2 & 8,3 & 4,6 \\
\hline 5 & Savings ability $\left(\mathrm{F}_{15}\right)$ & 11,0 & 8,5 & 7,4 & 5,1 \\
\hline 6 & $\begin{array}{l}\text { Opportunity to insure property, } \\
\text { life, health }\left(\mathrm{F}_{16}\right)\end{array}$ & 6,2 & 5,1 & 8,0 & 3,8 \\
\hline 7 & $\begin{array}{l}\text { Availability of housing, land, } \\
\text { car, etc. }\left(\mathrm{F}_{17}\right)\end{array}$ & 7,7 & 7,2 & 9,6 & 6,9 \\
\hline 8 & $\begin{array}{l}\text { Rich parents, relatives, } \\
\text { friends }\left(\mathrm{F}_{18}\right)\end{array}$ & 10,0 & 14,7 & 9,0 & 6,0 \\
\hline 9 & Lotteries, Legacy (F19) & 4,0 & 7,2 & 5,7 & 1,9 \\
\hline 10 & $\begin{array}{l}\text { Non-labor income (ability to } \\
\text { steal, not pay tax) (F20) }\end{array}$ & 8,9 & 11,4 & 7,1 & 4,3 \\
\hline \multicolumn{6}{|c|}{ Intangible factors $F_{2}$} \\
\hline 1 & Education $\left(\mathrm{F}_{21}\right)$ & 21,5 & 20,3 & 19,0 & 20,5 \\
\hline 2 & Quality of medical care $\left(\mathrm{F}_{22}\right)$ & 12,0 & 18,0 & 16,0 & 22,0 \\
\hline 3 & State social guarantees $\left(\mathrm{F}_{23}\right)$ & 9,7 & 7,4 & 10,0 & 5,6 \\
\hline 4 & $\begin{array}{l}\text { Effectiveness of the work of } \\
\text { social protection authorities }\left(\mathrm{F}_{24}\right)\end{array}$ & 7,5 & 5,2 & 8,1 & 8,1 \\
\hline 5 & $\begin{array}{l}\text { Work of the Judiciary, } \\
\text { Prosecutor's, Police }\left(\mathrm{F}_{25}\right)\end{array}$ & 12,4 & 8,1 & 7,8 & 10,0 \\
\hline 6 & Political stability $\left(\mathrm{F}_{26}\right)$ & 9,0 & 9,9 & 11,9 & 7,2 \\
\hline 7 & $\begin{array}{l}\text { Political system (Regime, } \\
\text { Democracy) }\left(\mathrm{F}_{27}\right)\end{array}$ & 6,8 & 9,3 & 5,0 & 5,1 \\
\hline 8 & Civil Society Institutions $\left(\mathrm{F}_{28}\right)$ & 6,0 & 6,7 & 7,0 & 2,1 \\
\hline 9 & Employment system $\left(\mathrm{F}_{29}\right)$ & 8,0 & 9,0 & 9,2 & 10,0 \\
\hline 10 & $\begin{array}{l}\text { The loyalty of the company } \\
\text { management (organization) }\left(\mathrm{F}_{30}\right)\end{array}$ & 7,1 & 6,0 & 6,0 & 9,5 \\
\hline
\end{tabular}


For the posterior sets of baseline statistics, 10 were selected for each group of factors. To construct a generalized index - an integral index LPH $\left(\mathrm{I}_{\mathrm{LPH}}\right)$ on selected aspects one of the methods of multidimensional statistics is applied - the principal component method ${ }^{8}$. A necessary procedure for measuring LPH is the preliminary unification of the selected base indicators, i.e. the application to them of such a transformation, which will result in all of them being measured in an $\mathrm{N}-$ point scale. In this case, the zero value of the transformed indicator will correspond to the lowest level of LPH by the respondents, and the maximum value of $\mathrm{N}$ - to the highest. Such unification will ensure comparability and comparability of the created information base. For stimulus indicators, the growth of which contributes to an increase in the LPH index, the value of the corresponding unified variable was calculated by the formula (1):

$$
F_{i r j}=\frac{\tilde{F}_{i r j}-\tilde{F}_{r j \min }}{\widetilde{F}_{r j \max }-\widetilde{F}_{r j \min }} N,
$$

where $F_{i r j}$-is the $i$-th value of the $j$-th base of the unified index of the $r$-th aspect LPH $F_{r j} \quad\left(i=\overline{1, n}, r=\overline{1,3}, j=\overline{1, m}_{r}, n-\right.$ the number of observations of the base indicator $F_{r j}, m_{r}$ - the number of base indicators of the $r$-th aspect of the LPH, which were considered);

$\tilde{F}_{i r j}-$ the $i$-th value of the $j$-th base is not unified indicator of the $r$-th aspect of the LPH $\tilde{F}_{r j}$;

$\tilde{v}_{r \text { min }}$ - the minimum value of the $j$-th base is not unified indicator of the $r$-th aspect of the LPH $\tilde{F}_{r j}$;

$\widetilde{F}_{r j \max }$ - the maximum value of the $j$-th base is not unified indicator of the $r$-th aspect of the LPH $\tilde{F}_{r j}$.

The calculation of integral indicators $X_{r}(r=\overline{1,4})$, which characterize certain aspects of the LPH, was carried out according to the formula:

$$
X_{r}=\sum_{j=1}^{m_{r}} w_{r j} F_{r j},
$$

where $w_{r j}$ - the weight with which the $j$-th indicator $r$-th aspect LPH is taken into account when calculating the integral index.

\footnotetext{
8 Айвазян С.А. К методологии измерения синтетических категорий качества жизни населения. Экономические и математические методы. 2003. Т. 39. № 2. С. 33-53.
} 
Weights $w_{r j}$ were calculated by two methods. In the first case, the weights $w_{r j}$ were defined as the part of dispersion $D\left(F_{r j}\right)$ of the indicator $F_{r j}$ in the total dispersion of all partial criteria of the $r$-th block:

$$
w_{r j}=\frac{D\left(F_{r j}\right)}{\sum_{j=1}^{m_{r}} D\left(F_{r j}\right)} .
$$

The construction of the integral index of a particular aspect of the LPH is in the second way carried out using the method of factor analysis modified first principal component.

The procedure for constructing the first principal component is based on the following basic idea. Among all the scalar variables characterizing a some aspect of the LPH, we are looking for the one with the most accurate values (using appropriate linear regression models) of the values of all partial criteria $F_{1}, F_{2}, \ldots, F_{m}$, that are considered (hereinafter, the index $r$ corresponding to the LPH aspect, is omitted). The construction of the first major component was by the following procedure:

1. Based on the original values of unified indicators of some aspect of LPH $F_{1}, F_{2}, \ldots, F_{m}$, standardized values of these indicators are calculated $F_{1}^{*}, F_{2}^{*}, \ldots, F_{m}^{*}$ and the matrix $F^{*}$ of standardized values of the output factors and the matrix of paired correlations were constructed:

$$
R=\frac{1}{n} F^{* T} F^{*} .
$$

2. To calculate the first principal component $F_{1}=l_{1} \mathbf{X}^{*}$ an optimization problem was solved:

$$
\left\{\begin{array}{c}
D\left(l_{1} F^{*}\right) \rightarrow \max _{l_{1}} ; \\
l_{1} l_{1}^{T}=1,
\end{array} .\right.
$$

System of equations to determine $l_{1}$ has the form:

$$
\left(R-\lambda_{1} I_{m}\right) l_{1}^{T}=0,
$$

where $\lambda_{1}$ - the largest eigenvalue of the matrix $R$, which we find by solving the characteristic equation $\left|R-\lambda I_{m}\right|=0$;

$I_{m}$ - unitary matrix of dimension $m$.

Thus, the first principal component $F_{1}$ is obtained as a linear combination: 


$$
F_{1}\left(F^{*}\right)=l_{1} F^{*},
$$

where $l_{1}$ - matrix eigenvector $R$, which corresponds to the largest eigenvalue $\lambda_{1}$ of this matrix.

As a measure of informativeness of the first major component $F_{1}$ the proportion $k$ of the total dispersion of this component in the total dispersion of the initial indicators is determined:

$$
k=\frac{D\left(F_{1}\right)}{D\left(F_{1}^{*}\right)+\ldots+D\left(F_{m}^{*}\right)} .
$$

Since $D\left(F_{1}\right)=\lambda_{1}, D\left(F_{1}^{*}\right)=\ldots=D\left(F_{m}^{*}\right)=1$, the criterion of informativeness can be represented as:

$$
k=\frac{\lambda_{1}}{m} .
$$

The disability area of a single scalar indicator of some aspect of the LPH is determined by the inequality:

$$
k<k^{*}
$$

According to the modified main component method, when calculating according to the formula (11) as weights $w_{r j}$ used squares components $j$ eigenvector $l_{1}$ covariance matrix of variables $F_{1}, F_{2}, \ldots, F_{m}$.

Construction of generalized LPH index of higher level $\mathrm{X}$ was by the formula:

$$
X=\sum_{r=1}^{2} w_{r} X_{r},
$$

where weights $w_{r}$ are defined as parts of dispersions $D\left(X_{r}\right)$ of the integral indicators $X_{r}$ in the total dispersion:

$$
w_{r}=\frac{D\left(X_{r}\right)}{\sum_{j=1}^{2} D\left(X_{r}\right)} .
$$

The calculation of the generalized LPH indicators was carried out using the SPSS statistical software package. It was assumed that $\mathrm{N}=10$. Note that in the calculations using the modified first principal component method, the variance explained by the first principal component was more than $50 \%$ for all aspects of the LPH considered, that is, in all cases the criterion efficiency of the method was performed. 
In the table 3 shows the calculation of the total dispersion, explained by the first principal component for constructing the matrix of components for the "Material factors" (Table 4).

Table 3

The total variance explained by the first principal component (Total Variance Explained)

\begin{tabular}{|c|c|c|c|c|c|c|}
\hline \multirow{2}{*}{$\begin{array}{c}\text { Compo } \\
\text { nent }\end{array}$} & \multicolumn{3}{|c|}{ Initial Eigenvalues } & \multicolumn{3}{|c|}{$\begin{array}{c}\text { Extraction Sums } \\
\text { of Squared Loadings }\end{array}$} \\
\cline { 2 - 7 } & Total & $\begin{array}{c}\text { \% of } \\
\text { Variance }\end{array}$ & $\begin{array}{c}\text { Cumulative } \\
\%\end{array}$ & Total & $\begin{array}{c}\text { \% of } \\
\text { Variance }\end{array}$ & $\begin{array}{c}\text { Cumulative } \\
\%\end{array}$ \\
\hline 1 & 5,855 & 68,832 & 58,552 & 5,855 & 58,552 & 58,552 \\
\hline 2 & 2,546 & 7,888 & 84,010 & & & \\
\hline 3 & 1,599 & 6,052 & 100,000 & & & \\
\hline 4 & 0 & 0 & 100,000 & & & \\
\hline 5 & 0 & 0 & 100,000 & & & \\
\hline 6 & 0 & 0 & 100,000 & & & \\
\hline 7 & 0 & 0 & 100,000 & & & \\
\hline 8 & 0 & 0 & 100,000 & & & \\
\hline 9 & 0 & 0 & 100,000 & & & \\
\hline 10 & 0 & 0 & 100,000 & & & \\
\hline
\end{tabular}

Extraction Method: Principal Component Analysis.

Table 4

Component Matrix(a)

\begin{tabular}{|c|c|}
\hline Component & Value \\
\hline$\widetilde{F}_{11}$ &,- 780 \\
\hline$\widetilde{F} 12$ &,- 803 \\
\hline$\widetilde{F} 13$ &,- 965 \\
\hline$\widetilde{F} 14$ &, 563 \\
\hline$\widetilde{F} 15$ &, 980 \\
\hline$\widetilde{F} 16$ &, 621 \\
\hline$\widetilde{F} 17$ &, 867 \\
\hline$\widetilde{F} 18$ &, 575 \\
\hline$\widetilde{F} 19$ &, 560 \\
\hline$\widetilde{F}_{20}$ &,- 783 \\
\hline
\end{tabular}

Extraction Method: Principal Component Analysis 
The table 5 shows the calculation of the integral LPH index, calculated according to the first and other methods.

Table 5

Calculation of factor values for construction of integral index of LPH by material factors

\begin{tabular}{|c|c|c|c|c|}
\hline Factor & $X_{1}^{(I)}$ & $X_{2}^{(I)}$ & $X_{3}^{(I)}$ & $X_{4}^{(I)}$ \\
\hline $\mathrm{F}_{11}$ & 0,83 & 0 & 2,59 & 10 \\
\hline $\mathrm{F}_{12}$ & 10 & 6,67 & 6,67 & 0 \\
\hline $\mathrm{F}_{13}$ & 10 & 5 & 0 & 3,57 \\
\hline $\mathrm{F}_{14}$ & 10 & 8,07 & 6,49 & 0 \\
\hline $\mathrm{F}_{15}$ & 10 & 5,8 & 3,9 & 0 \\
\hline $\mathrm{F}_{16}$ & 5,71 & 3,1 & 10 & 0 \\
\hline $\mathrm{F}_{17}$ & 2,96 & 1,11 & 10 & 0 \\
\hline $\mathrm{F}_{18}$ & 4,60 & 10 & 3,45 & 0 \\
\hline $\mathrm{F}_{19}$ & 3,96 & 10 & 7,17 & 0 \\
\hline $\mathrm{F}_{20}$ & 3,52 & 0,0 & 6,06 & 10 \\
\hline
\end{tabular}

Table 6

The calculation of the integral index of the LPH performed by the first and other methods

\begin{tabular}{|c|c|c|c|c|}
\hline Factor & $X_{1}^{(I)}$ & $X_{2}^{(I)}$ & $X_{3}^{(I)}$ & $X_{4}^{(I)}$ \\
\hline $\mathrm{Y}_{11}$ & 6,55 & 4,36 & 5,15 & 2,65 \\
\hline $\mathrm{Y}_{12}$ & 6,47 & 4,28 & 4,09 & 2,58 \\
\hline
\end{tabular}

The analysis of the table 5 and Table 6 shows the comparability of the results obtained by the first and second methods. Higher factor values were obtained by the modified principal method component, which shows the benefits of this method over the first one. In the table. 7 shows the calculation of the total variance, which is explained by the first principal component for constructing a component matrix by "Intangible factors".

The calculation of the values of the factors for the construction of the integral index of the LPH on the material factors is presented in table 8. 
The total variance that is explained

by the first principal component (Total Variance Explained)

\begin{tabular}{|c|c|c|c|c|c|c|}
\hline \multirow{2}{*}{$\begin{array}{c}\text { Compo- } \\
\text { nent }\end{array}$} & \multicolumn{3}{|c|}{ Initial Eigenvalues } & \multicolumn{4}{c|}{$\begin{array}{c}\text { Extraction Sums } \\
\text { of Squared Loadings }\end{array}$} \\
\cline { 2 - 7 } & Total & $\begin{array}{c}\text { \% of } \\
\text { Variance }\end{array}$ & $\begin{array}{c}\text { Cumulative } \\
\%\end{array}$ & Total & $\begin{array}{c}\text { \% of } \\
\text { Variance }\end{array}$ & $\begin{array}{c}\text { Cumulative } \\
\%\end{array}$ \\
\hline 1 & 4,860 & 48,603 & 48,603 & 4,860 & 48,603 & 48,603 \\
\hline 2 & 2,952 & 29,524 & 78,127 & & & \\
\hline 3 & 2,187 & 21,873 & 100,0 & & & \\
\hline 4 & 0 & 0 & 100,0 & & & \\
\hline 5 & 0 & 0 & 100,0 & & & \\
\hline 6 & 0 & 0 & 100,0 & & & \\
\hline 7 & 0 & 0 & 100,0 & & & \\
\hline 8 & 0 & 0 & 100,0 & & & \\
\hline 9 & 0 & 0 & 100,0 & & & \\
\hline 10 & 0 & 0 & 100,0 & & & \\
\hline
\end{tabular}

Extraction Method: Principal Component Analysis

Table 8

Component Matrix(a)

\begin{tabular}{|c|c|}
\hline Component & Value \\
\hline$\widetilde{F}_{11}$ &,- 780 \\
\hline$\widetilde{F} 12$ &,- 803 \\
\hline$\widetilde{F} 13$ &,- 965 \\
\hline$\widetilde{F} 14$ &, 563 \\
\hline$\widetilde{F} 15$ &, 980 \\
\hline$\widetilde{F} 16$ &, 621 \\
\hline$\widetilde{F} 17$ &, 867 \\
\hline$\widetilde{F} 18$ &, 575 \\
\hline$\widetilde{F} 19$ &, 560 \\
\hline$\widetilde{F}_{20}$ &,- 783 \\
\hline
\end{tabular}

The analysis of the table. 9 and table. 10 shows the comparability of the results obtained by the first and second methods. The higher factor values were obtained by the modified principal component method, which indicates the advantage of this method over the former. Based on the procedures of dimensionality reduction and construction of integral 
indicators, the rating for each calculated integral indicator is calculated as a generalized estimate.

\section{Table 9}

The calculation of the values of factors for the construction of the integral index of the LPH by material factors

\begin{tabular}{|c|c|c|c|c|}
\hline Фактор & $X_{1}^{(I I)}$ & $X_{2}^{(I I)}$ & $X_{3}^{(I I)}$ & $X_{4}^{(I I)}$ \\
\hline $\mathrm{F}_{21}$ & 10 & 5,2 & 0 & 6 \\
\hline $\mathrm{F}_{22}$ & 0 & 6 & 4 & 10 \\
\hline $\mathrm{F}_{23}$ & 9,32 & 4,09 & 10 & 0 \\
\hline $\mathrm{F}_{24}$ & 7,93 & 0 & 10 & 10 \\
\hline $\mathrm{F}_{25}$ & 10 & 0,7 & 0 & 4,8 \\
\hline $\mathrm{F}_{26}$ & 3,83 & 5,74 & 10 & 0 \\
\hline $\mathrm{F}_{27}$ & 4,19 & 10 & 0 & 0,23 \\
\hline $\mathrm{F}_{28}$ & 7,96 & 9,39 & 10 & 0 \\
\hline $\mathrm{F}_{29}$ & 0 & 5 & 6 & 10 \\
\hline $\mathrm{F}_{30}$ & 3,14 & 0 & 0 & 10 \\
\hline
\end{tabular}

Table 10

Calculation of integral index of LPH, conducted by the first and other methods

\begin{tabular}{|c|c|c|c|c|}
\hline Фактор & $X_{1}^{(I I)}$ & $X_{2}^{(I I)}$ & $X_{3}^{(I I)}$ & $X_{4}^{(I I)}$ \\
\hline $\mathrm{Y}_{21}$ & 5,52 & 4,34 & 5,02 & 5,28 \\
\hline $\mathrm{Y}_{22}$ & 5,46 & 4,26 & 4,69 & 5,19 \\
\hline
\end{tabular}

Thus, the survey conducted and the application of the above methods made it possible to find out that by the first group of factors (F1), the pupils who rated material factors higher than the other groups of respondents received the highest value of the integral factor of 6.55 (tabl.6). The second highest value of 5.15 is the integral coefficient obtained by the workers; 4.36 received students and 2.65 pensioners. The highest value of the integral coefficient in the second group of factors (F2) 5.52 was obtained by students who ranked humanitarian factors above the other groups. 5.28 - by pensioners, 5.02 - by workers and 4.34 - by students. Students in the second group of factors (F2), who ranked humanitarian factors above the other groups, 5.28 - by pensioners, 5.02 - by workers and 4.34 - by students, obtained the highest value of the integral coefficient 5.52. The results of the calculations made by the second method are almost similar. 
Among the material factors, the largest number of points 107.5 received "income", 42.6 - "prices", 41.7 - "taxes". Among humanitarian factors, the highest score was 115.1 for education, 68 for health care and 38.3 for the judiciary.

\section{CONCLUSIONS}

The concept of the effectiveness of those or other activities is often subjective. But there are generally accepted criteria that allow to evaluate the success of a case and talk about its effectiveness. This is especially important when it comes to evaluating social protection measures, since most of them are financed from local or state budgets.

The modern system of financing the social sphere in Ukraine is based mainly on estimated financing, which is based on the costly method. For market conditions, it is not entirely appropriate, since it does not contain mechanisms to stimulate the quality and quantity of services; creates interest in increasing costs (the size of financing next year depends on it); requires institutions and organizations in the social sphere to have a control mechanism at all stages of the process of creating a service. In addition, most importantly, it inhibits the development of market relations in the sectors of the social sphere, since it is oriented, when choosing a service provider, mainly to government organizations in this sphere. Over the past few years, the principle of cost saving has prevailed in social policy. However, this principle does not always mean rational or optimal use.

The proposed method for assessing the effectiveness of financing of social protection of the population (namely the coefficient of efficiency of the using budgets resources, which is conducted in three stages) can be used to determine the effectiveness of the implementation of social programs or individual social protection measures. It makes it possible to evaluate not only the nature of the use of funds for the event, but also the social effect of it.

Sometimes it is advisable to evaluate in relative indicators (in points). The example, shown by us, demonstrates how this can be done when processing the data of a sociological survey.

One of the prerequisites for effective financial support of social protection of the population is the use of real and scientifically sound norms and financial standards. In Ukrainian legislation, the classification of social standards is carried out according to two criteria: by the nature and degree of satisfaction of social needs; classification of social standards according to the main spheres of human life: education, healthcare, culture, 
etc. This means that the standards should reflect the provision of the population with everything necessary for the organization of everyday life. But the size of social norms established by the state in many cases is determined without sufficient justification and is revised depending on the inflation rate and available financial resources, and often for political reasons.

Prospects for further research in this direction. Therefore, to eliminate these problems, we need a transition from estimated financing of those activities that are related to the provision of social services, to more market mechanisms - normative per capita financing and financing based on a social order. The introduction of normative per capita financing allows optimizing the resources of the social sectors, increasing the transparency of the budget process, and evening out the budgetary provision of the territories. And financing on the basis of a social order means connecting social institutions to the system of competitive bidding and public procurement. True, the transition to normative financing of the social sphere is difficult due to the lack of standard methods for calculating per capita financial standards, which require a system of natural social standards.

\section{SUMMARY}

The article deals with scientific and methodological approaches to assessing the effectiveness of financing social protection measures. A number of approaches to determining the effectiveness of social service delivery have been generalized. It is noted that the principle of cost savings does not always mean rational or optimal use. The state policy of optimization during medical reform and in the sphere of education in Ukraine has been criticized. It is proved that in order to finally determine the effectiveness of financial support for social protection, it is necessary to calculate not only the economic efficiency of expenditures, but also the social effect of the measures carried out. A method of assessing the effectiveness of financing for social protection is proposed, which can be used to determine the effectiveness of the implementation of social programs or individual measures of social protection, which makes it possible to assess not only the nature of the use of funds for the event, but also the social effect of it. The method of the principal component was used to calculate the integral coefficient in determining the significance of factors of socio-economic security of households in the course of a sociological survey. 


\section{REFERENCES}

1. Pigou, A. C. (1920). The Economics of Welfare. London: Macmillan, 953 p. URL: http://pombo.free.fr/pigou1920.pdf

2. The Economics of Welfare. URL: https://www.britannica.com/ topic/The-Economics-of-Welfare

3. Samuelson P. Diagrammatic exposition of the theory of public expenditure. Review of Economics and Statistics. Vol. 37. No. 4 (Nov. 1955), pp. 350-356.

4. Тропіна В.Б. Фіскальне регулювання соціального розвитку суспільства. Київ : НДФІ, 2008. 368 с.

5. Радіонов Ю. Проблема ефективності використання бюджетних коштів. Фінанси України. 2011. № 5. С. 47-55.

6. Соціальний захист населення України. Статистичний збірник. Відп. за випуск І.В. Калачова. Київ : Державна служба статистики України, 2012. 119 с.

7. Лановенко О.А. Социальная эффективность предоставления социальных услуг: критериальные показатели ее оценки. Вісник Харківського нащіонального університету імені В.Н. Каразіна. 2010. № 889. C. 142-147.

8. Айвазян С.А. К методологии измерения синтетических категорий качества жизни населения. Экономические и математические методы. 2003. Т. 39. № 2. С. 33-53.

\section{Information about the author:} Barannik L. B.

Doctor of Economics, Professor, Head of the Department of Taxation and Social Security, University of Customs and Finance, Ukraine 